\title{
Taphonomic Study of Adult Susscrofa domestica in Equatorial Climate in Sarawak, Malaysia
}

\author{
Ing TK, Ismail NA and Soon LP* \\ Department of Forensic Medicine, National Institute of \\ Forensic Medicine, Malaysia \\ *Corresponding author: Lai Poh Soon, Department \\ of Forensic Medicine, National Institute of Forensic \\ Medicine Hospital Kuala Lumpur, J alan Pahang, 50586 \\ Kuala Lumpur, Malaysia
}

Received: February 07, 2017; Accepted: February 24, 2017; Published: March 10, 2017

\begin{abstract}
Taphonomic study is first time conducted in Sarawak, Malaysia. In this research model, two adults female Susscrofa domestica weighed $77 \mathrm{~kg}$ each are killed by machete at the heart region. Then, the bodies are put clothes made of pure cotton on to mimic the real human body with clothes. Pure cotton clothes is a favourite for Malaysia's population due to hot and humid climate. Later on, the bodies are being placed in the separate location labelled A and B in jungle. Taphonomic changes is obeserved. All stages of decomposition like fresh stage, bloated stage, active decay stage, advanced decay stage and remains stage are observed and documented. Daily observation on both the bodies is conducted. The ambient temperature of surroundings, internal temperature of bodies, temperature of larvae mass, body surface temperature, soil surface temperature and humidity of air are recorded daily. Time for each stage of decomposition is determined. During the decomposition process, insects and larvae appeared in each stage of decomposition process are collected and preserved for reference. Photos and videos are taken for each subject throughout the research. The hot and humid climate in Sarawak accelerates the decomposition process. The time taken for both bodies to reach remains stage is nine days. Both the cotton clothes are still preserved by the end of research. As a conclusion, an equatorial climate is accelerating the decomposition process of body in Sarawak, Malaysia.
\end{abstract}

Keywords: Taphonomic study; Susscrofa domestica; Cotton clothes; Decomposition process; Equatorial climate

\section{Introduction}

Taphonomic study is a research which includes various discipline such as decomposition process, preservation, dispersion, buried and exposition of dead body [1]. Forensic taphonomy is an international endeavour which includes collecting the evidence in crime scene and interpretation of dead cases [2]. Forensic taphonomy is often linked with ecological aspect because carcass is considered as newly emerging microenvironment [3]. Taphonomic study is an actualistic research which shares common fundamental between traditional, paleontological taphonomy and forensic taphonomy [4]. Taphonomic study on adult Susscrofa domestica in humid climate in Malaysia is a study to mimic the real human body decomposition. In this study, cotton cloth is put onto the adult Susscrofa domestica due to the preference of Malaysian to wear sweat-absorbent material like cotton for daily dressing. Thus, it is highly possible to recover evidence of clothing material that is important to forensic investigation because in criminal cases clothing will normally be intact, but may be disturbed by taphonomic process [2]. Besides that, murder case is quite common and the body is usually dumped in the rural area or open field in jungle. Hence, the important thing is that we would like to find out the decomposition rate and taphonomic changes in order to deduce the post-mortem interval as well as estimation of time of death.

Apart from that, cadaver is the food source that will initiate the complex cycle of tropic phase like decomposition process, assimilation, and dispersion [5]. Cadaver also caused the chemical, temperature and soil composition changes of the environment [6,7]. Thus, taphonomic research is very dependent on the environmental factor and local condition such as atmosphere, lithosphere, biosphere, decomposition process, preservation technique and condition of buried [8]. During the decomposition process, cadaver is break down into smaller material and absorb into the soil, washed away by rain, eaten up by insects or evaporated into the air [2]. Taphonomic data is useful as forensic evidence to determine original death place, ways of transportation body, criminal activities, and post-mortem interval determination [8].

In Malaysia, there are several researches conducted to evaluate the insect succession pattern as well as decomposition process of pigs in palm oil plantation [9,10]. Malaysia is located in Equator. Equatorial climate in Malaysia contribute to high and stable temperature throughout the year. Annual mean temperature of Malaysia is $27.3^{\circ} \mathrm{C}$ except Genting Highlands and Cameron Highlands which have the lower annual mean temperature of $18.6^{\circ} \mathrm{C}[11]$.

The taphonomy study is conducted in small village known as Bintangor located in Sarawak, East Malaysia. This is the pioneer research of taphonomic study in Sarawak. In this research model, two female adults Susscrofa domestica weighed $77 \mathrm{~kg}$ each is selected due to its size that can resemble the adult human body. Susscrofa domestica as a human body surrogates is an acceptable manner for scientific research [2]. For the taphonomic study, adults Susscrofa domestica is used as analogue for human body due to its characteristic lack of fur, almost same weight with normal human body, and easily 


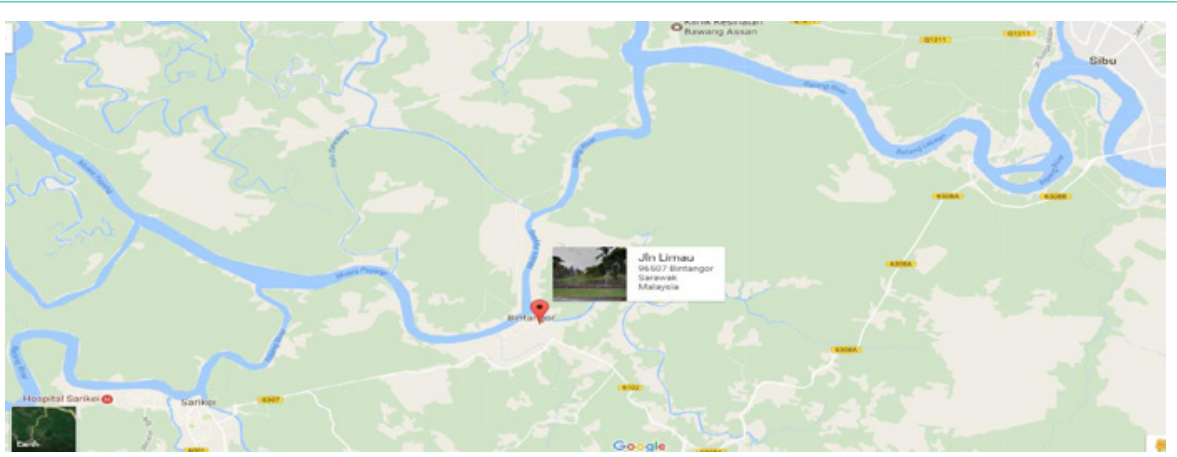

Figure 1: Map of the location (marked with red circle).

obtain from market [12-14]. Apart from that, the decomposition process for Susscrofa domestica is almost same with the human body. The decomposition time for each stage is almost same with human body under the same environment condition [13].

Hence, the taphonomic study of adult Susscrofa domestica in Equatorial climate in Bintangor, Sarawak can mimic the real decomposition process of human body. This pioneer taphonomic research can generate a complete set of data sheet which includes pattern of insect succession, post-mortem interval determination based on the decomposition rate, effects of cotton clothes on the decomposition process, effects of Equatorial climate on the research study and comparison of research study between West Malaysia and East Malaysia in the aspects of decomposition rate. The outcome of this study can benefit the enforcement body in the investigation of crime scene involved the human body as well as the researchers in this field. This study has obtained ethical clearance from Animal Ethics Committee of the National University of Malaysia.

\section{Methodology}

Two adults Susscrofa domestica carcasses weighing $77 \mathrm{~kg}$ each were used in this study. Both of them were killed by piercing at the heart region with machete. After that, both the carcasses were put on the pure cotton clothes. Later, the pigs were put on top of the jungle floor separately which labeled Site A and Site B. Bothe the sites are 120 meters away from each other. Fencing $(120 \mathrm{~cm} \times 70 \mathrm{~cm} \times 48 \mathrm{~cm})$ was provided to protect the carcasses from animals. This study was conducted in the morning of the month of May, which was taken as the first day in the jungle of Bintangor, Sarawak with Equitorial climate.

Observations were made for 26 days with 3 visits per day except first day. First visit was in the morning ( 8 a.m.), second visit was in the noon (12 p.m.) and third visit is afternoon (6 p.m.). First day observation was conducted 4 times (11 a.m., 1 p.m., 6 p.m., and 9 p.m.) to evaluate the changes of the carcass deeply. Climatological data such as ambient temperature and humidity were recorded for 26 days by using digital thermometer and hygrometer. Ground temperature, body surface temperature, internal temperature and maggot mass temperature were taken for each visit. Adult flies were caught by using sweep net. Some of the fly larvae were collected using forceps and put into ethyl alcohol $70 \%$ for preservation [15]. The specimens were processed for storage and kept as record in the Forensic Science Department, Faculty of Allied Health Sciences, and

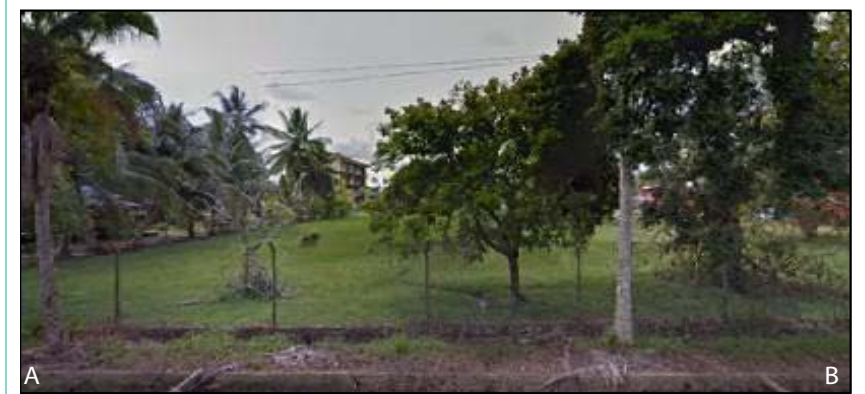

Figure 2: Location of the study (Site A and Site B).

Table 1: Stages of decomposition.

\begin{tabular}{|c|c|c|}
\hline \multirow{2}{*}{ Stage } & Susscrofa domestica A & Susscrofa domestica B \\
\cline { 2 - 3 } & Day & Day \\
\hline Fresh & 1 & 1 \\
\hline Bloated & $2-3$ & $2-3$ \\
\hline Active decay & $4-6$ & $4-6$ \\
\hline Advanced decay & $7-8$ & $7-8$ \\
\hline Remains & $9-26$ & $9-26$ \\
\hline
\end{tabular}

The National University of Malaysia.

\section{Results}

The air humidity in the jungle of Bintangor, Sarawak for the 26 days ranged from $69 \%$ to $93 \%$ (mean $83.54 \pm 6.21 \%$ ) at site A while ranged from $73 \%$ to $95 \%$ (mean $85.27 \pm 6.00 \%$ ) at site B. Three times of raining were recorded during the study (day-1, 9 and 13).

The ambient temperature ranged from $27.1^{\circ} \mathrm{C}$ to $32.4^{\circ} \mathrm{C}$ (mean $30.17 \pm 1.34^{\circ} \mathrm{C}$ ) at site A while ranged from $27.0^{\circ} \mathrm{C}$ to $31.9^{\circ} \mathrm{C}$ (mean $29.85 \pm 1.32^{\circ} \mathrm{C}$ ) at site B. Ground surface temperature recorded ranged from $26^{\circ} \mathrm{C}$ to $28^{\circ} \mathrm{C}$ (mean $27.38 \pm 1.32^{\circ} \mathrm{C}$ ) at site A while ranged from $27^{\circ} \mathrm{C}$ to $31^{\circ} \mathrm{C}$ (mean $28.46 \pm 1.30^{\circ} \mathrm{C}$ ) at site $\mathrm{B}$.

Maggot mass temperature varied from $33^{\circ} \mathrm{C}$ to $48^{\circ} \mathrm{C}$ (mean $43.14 \pm 4.85^{\circ} \mathrm{C}$ ) at site A while ranged from $28^{\circ} \mathrm{C}$ to $51^{\circ} \mathrm{C}$ (mean $42.4 \pm 7.79^{\circ} \mathrm{C}$ ) at site B. Internal temperature ranged from $27^{\circ} \mathrm{C}$ to $50^{\circ} \mathrm{C}$ (mean $39.23 \pm 7.34^{\circ} \mathrm{C}$ ) at site $\mathrm{A}$ while ranged from $27^{\circ} \mathrm{C}$ to $55^{\circ} \mathrm{C}$ (mean $\left.37.73 \pm 8.27^{\circ} \mathrm{C}\right)$ at side $\mathrm{B}$.

All of the decomposition processes were taken certain period of time. From the graph (Figure 1,2), there was a higher temperature of 


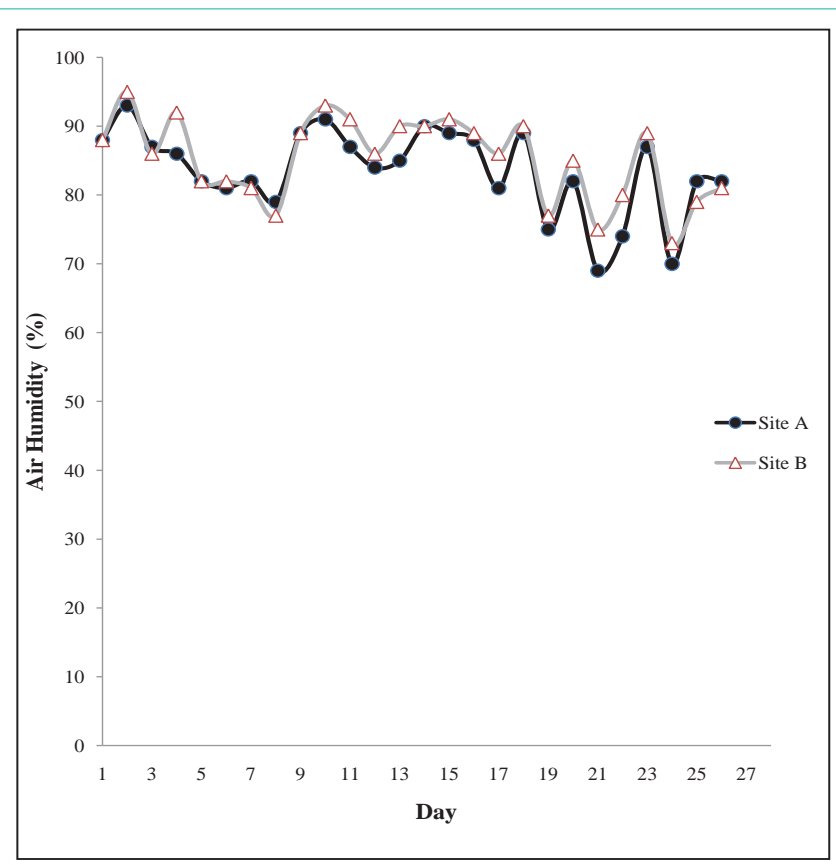

Figure 3: Air humidity in Bintangor, Sarawak.

maggot mass temperature and internal temperature.

Five stages of decomposition process were observed in the study. There were fresh, bloated, active decay, advanced decay and remains (Table 1).

\section{Discussion}

In this study, two adults Susscrofa domestica displayed the five stages of decomposition process [13]. Each stage of it displayed certain time period (Table 1). The cotton clothes on the carcass are to mimic the real human body that still has clothes intact on it. Cotton clothes are widely used in Equatorial climate [16]. The clothes have little or no significant effects on the decomposition process. This phenomenon can be explained through the research done in West Malaysia [10]. The carcass without the clothes on the body showed the same decomposition process time with the carcasses in Bintangor, Sarawak. Overall, the clothes is not decomposed and still preserved in good condition. Only slightly colour changes from original blue to brown due to contamination by putrefaction fluid. Generally, the textile material will undergo different rate of decomposition and greatly depends on the composition, colouring, and treatment done on the textile [2]. The cotton clothes cannot withstand the acidic environment. The putrefaction process will alter the surroundings and eventually promote the microorganism activity, increase the $\mathrm{pH}$ and redox reactions [17]. The clothes in the study are still well preserved due to the blue synthetic colour used on the clothes. The coloured-synthetic pigment can prevent the clothes from being decomposed [18].

The air humidity in Bintangor, Sarawak is high and always above $65 \%$ during the study (Figure 3). Air humidity is higher in the morning and afternoon if compare to noon due to heating effects by sun. Bintangor in Sarawak displayed Equatorial climate

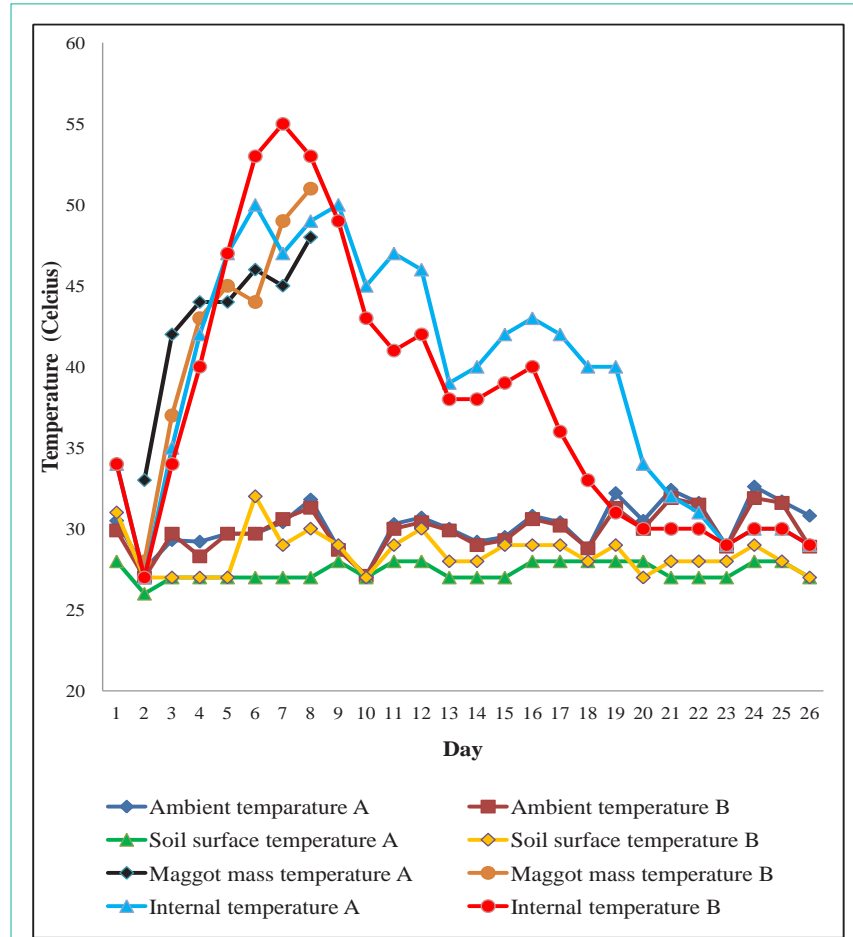

Figure 4: Data from site $A$ and site $B$.

characteristic. Thus, it will accelerate the decomposition process of Susscrofa domestica. Cadaver has $60 \%$ to $80 \%$ water inside the tissue. During the decomposition process, there is competition of water between the decomposition and drying process [19]. In an extremely humid condition, decomposition process will slow down due to saturated water in the tissue [20]. On the other hand, humidity is positively correlated with the insect's activity [5]. Further research had proven that rain has little or no effects on the insect's activity [5]. In this study, the adult flies were reduced greatly during the rain but the larvae were still active. During the rain, adult flies were hiding inside the clothes worn by the carcass and behind the leaves.

Taphonomic study in Bintangor, Sarawak showed the ambient temperature of site A and site B were high, stable and displayed same data distribution pattern (Figure 4). Ambient temperature is vital and influential in decomposition process $[5,20]$. Thus, faster rate of decomposition is observed in high ambient temperature [21]. The ambient temperature of Bintangor, Sarawak is always over $25^{\circ} \mathrm{C}$ during the study. Thus it is promoting faster decomposition rate on the both the carcass.

The ground surface temperature of site $\mathrm{A}$ and site $\mathrm{B}$ show temperature over $25^{\circ} \mathrm{C}$ but lower $31^{\circ} \mathrm{C}$ (Figure 4). Ground surface temperature did not fluctuate drastically according to the ambient temperature. Generally, the ground surface temperature is always cooler due to shading effect from the surroundings trees. So far there is no research being conducted and proven that there is correlation between decomposition process and ground surface temperature.

Two major species of blowflies were identified i.e. Chrysomya megacephala and Chrysomya rufifacies. Maggot mass temperature was recorded from the beginnings since the emergence of the first 

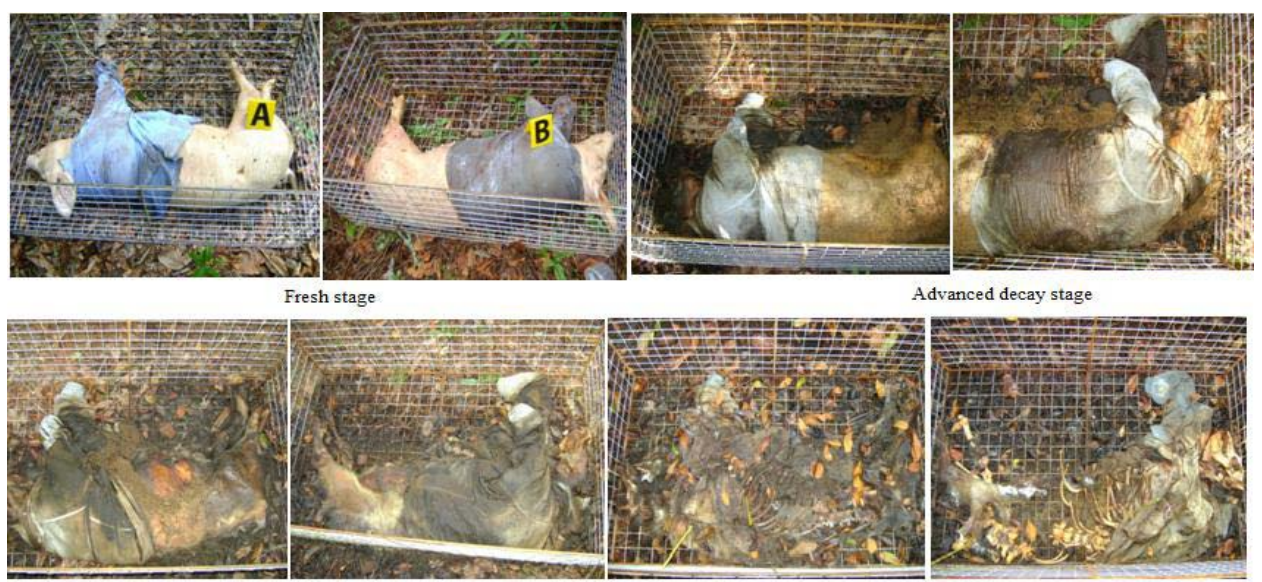

Advanced decay stage

Advanced decay stage

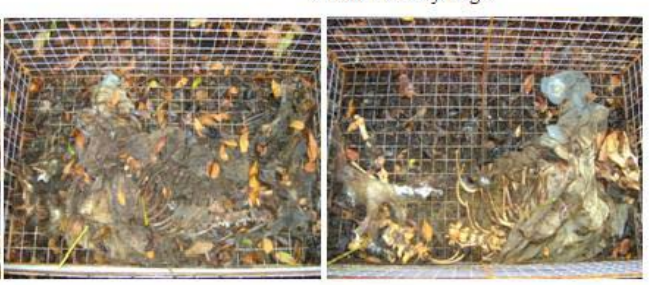

Remains

Figure 5: Different stages.

instar larvae which initially feeds on fluid exuded from the carcass. The first instar larva was usually found at the mouth region which filled with bloody fluid due to the internal trauma [22]. On the other hand, the maggot mass temperature had no different with the ambient temperature but increased drastically during the emergence of the third instar larvae [21]. The maggot mass temperature of site $\mathrm{A}$ and site $\mathrm{B}$ reached around $50^{\circ} \mathrm{C}$ (Figure 4) during advanced decomposition stage (Table 1). Maggot mass temperature is always higher than ambient temperature [21]. Increased decomposition rate is directional proposed to the increased temperature [5]. In addition, the clothing worn by the carcass was providing heat to the eggs and larvae [22]. Maggot mass temperature increased drastically due to increased rate of decomposition process and biological activity [23]. Maggot mass temperature started to increase on the second day which was the bloated stage for the carcasses. No maggot mass temperature was recorded on the ninth day which was the remains stage commenced. This phenomenon was due to depletion of tissue for maggot consumption and all maggots had fully developed into adult flies. New maggot emergence was impossible due to lack of interest of adult flies to lays eggs on the remains.

Apart from that, internal temperature of both Susscrofa domestica is $55^{\circ} \mathrm{C}$ which is highest during the advanced decay stage (Figure 2). This temperature is equal to the maggot mass temperature. Thus, the active decomposition process was taken place. Furthermore, increased rate of decomposition and biological activity will directly elevate the temperature [23]. From this study, the internal temperature started to drop on $9^{\text {th }}$ day (Figure 5) signaling beginning of remains stage and decreased maggot activity. The decomposition process is decreased due to depleted soft tissue for further autolysis. The amount of insect presence was greatly deduced. According to Payne (1965), to determine starting point of remains stage immediately after the advanced decay stage is difficult. However, the starting point of remains can be determined by the surrounding flora or weeds around the carcasses. On the other hand, no growing of flora or weeds was clearly observed in the study conducted in Bintangor, Sarawak. Thus, the guideline of observing the starting point of remains stage cannot be applied in this study. However, the internal temperature and maggot mass temperature are the most appropriate way to determine each of the decomposition stage.

\section{Conclusion}

In conclusion, the taphonomic study in Bintangor, Sarawak showed that five stages of decomposition is clearly defined and each of the stages taken certain time period. The cotton clothes had little or no significant effect on the decomposition process as the ambient temperature effect outweighed the clothing effect. The Equatorial climate in Bintangor, Sarawak has increased the rate of decomposition process. The decomposition process of carcass in West Malaysia and East Malaysia (Bintangor, Sarawak) is almost same.

\section{References}

1. Ururahy-Rodrigues A, Rafael JA, Wanderley RF, Marques $\mathrm{H}$, Pujol-Luz JR. Coprophanaeus lancifer (Linnaeus, 1767) (Coleoptera, Scarabaeidae) activity moves a man-size pig carcass: Relevant data for forensic taphonomy. Forensic Sci Int. 2008; 182: E19-E22.

2. Haglund WD, Sorg MH. Advances in Forensic Taphonomy: Method, Theory, and Archaeological Perspectives. New York: CRC Press; 2002.

3. Kormondy EJ. Brown DE. Fundamentals of Human Ecology, Upper Saddle River, NJ: Prentice Hall; 1998.

4. Gifford-Gonzolez DP. Taphonomy and paleoecology : A critical review of archaeology's sister disciplines. In Advances in Archeological Method and Theoryed. Schiffer MB. New York: Academic Press; 1981.

5. Mann RW, Bass WM, Meadows L. Time since death and decomposition of the human body: variables and observations in case and experimental field studies. J Forensic Sci. 1990; 35: 103-111.

6. Benninger LA, Carter DO, Forbes SL. The biochemical alteration of soil beneath a decomposing carcass. Forensic Sci Int. 2008; 180: 70-75.

7. Coe M. The decomposition of elephant carcasses in the Tsavo (East) National Park, Kenya. Journal of the Arid Environments. 1978; 1:71-86.

8. Lyman RL. Vertebrate Taphonomy. New York: Cambridge University Press; 1994.

9. Azwandi A, Abu Hassan A. A preliminary study on the decomposition and dipteran associated with exposed carcasses in an oil palm plantation in Bandar Baharu, Kedah, Malaysia. Trop Biomed. 2009; 26: 1-10.

10. Heo CC, Mohamad AM, Ahmad Firdaus MS, Jeffery J, Baharudin O. A preliminary study of insect succession on a pig carcass in a palm oil plantation in Malaysia. Trop Biomed. 2007; 24: 23-27.

11. Chong MS. PMR Geografi (Selangor: Sasbadi Sdn. Bhd). 2007. 
12. Anderson GS, Cervenka VJ. Insects associated with the body: Their use and analyses. Advances in Forensic Taphonomy. 2002; 177-200.

13. Payne JA. A summer carrion study of the baby pig Sus scofa Linnaeus. Ecology. 1965; 46: 592-602.

14. Schoenly KG. Using pig carcasses as model corpses to teach concepts of forensic entomology \& ecological succession. American Biology Teacher. 2006; 68: 402-410.

15. Haskell NH, McShaffrey DG, Hawley DA, Williams RE, Pless JE. Use of aquatic insects in determining submersion interval. J Forensic Sci. 1989; 34: $622-632$.

16. Miller E. Textiles: Properties and Behaviour in Clothing Use. London: B.T. Batsford; 1992.

17. Janaway RC. The preservation of organic materials in association with metal art efacts deposited in inhumation graves. Boddington A, Garland AN, Janaway RC, editors. In Death Decay and Reconstruction : Approaches to Archeology and Forensic Sciences. Manchester: Manchester University Press; 1987.
18. Tibbett M, Carter DO, editors. Soil Analysis in Forensic Taphonomy Chemical and Biological Effects of Buried Human Remains. Boca Raton: CRC Press; 2008.

19. Aufderheide AC. Soft tissue paleopathology--an emerging subspecialty. Hum Pathol. 1981; 12: 865-867.

20. Campobasso CP, Di Vella G, Introna F. Factors affecting decomposition and Diptera colonization. Forensic Sci Int. 2001; 120: 18-27.

21. Joy JE, Liette NL, Harrah HL. Carrion fly (Diptera: Calliphoridae) larval colonization of sunlit and shaded pig carcasses in West Virginia, USA Forensic Sci Int. 2006; 164: 183-192.

22. Klotzbach $\mathrm{H}$. Information is Everything- A case report demonstrating the necessity of Entomological knowledge at the crime scene. Journal of Forensic Medicine and Toxicology. 2004; 5: 19-21.

23. Carter DO, Yellowlees D, Tibbett M. Cadaver decomposition in terrestrial ecosystems. Naturwissenschaften. 2007; 94: 12-24.
Austin J Forensic Sci Criminol - Volume 4 Issue 1 - 2017

ISSN : 2380-0801 | www.austinpublishinggroup.com

Soon et al. (C) All rights are reserved
Citation: Ing TK, Ismail NA and Soon LP. Taphonomic Study of Adult Susscrofa domestica in Equatorial Climate in Sarawak, Malaysia. Austin J Forensic Sci Criminol. 2017; 4(1): 1058. 